\title{
Single-cell response of bacterial groups to light and other environmental factors in the Delaware Bay, USA
}

\author{
Tiffany R. A. Straza, David L. Kirchman* \\ School of Marine Science and Policy, University of Delaware, 700 Pilottown Rd., Lewes, Delaware 19958, USA
}

\begin{abstract}
We examined the incorporation of leucine, protein, and a mixture of 15 amino acids by selected phylogenetic groups in light and dark incubations of coastal waters of the Delaware Bay and Mid-Atlantic Bight. In experiments conducted over $3 \mathrm{yr}$, the single-cell activity of different groups of bacteria varied with molecular weight of the substrate, photosynthetically active radiation (PAR), and other environmental conditions. The fraction of cells active in using leucine and incorporating protein differed among groups and between summer and fall. About $30 \%$ of all cells incorporated the amino acid mixture, while only $10 \%$ incorporated protein. PAR availability affected single-cell activity in $20 \%$ of all experiments, and PAR conditions prior to sampling correlated with light effects on singlecell activity, varying with the compound (amino acid mixture, leucine or protein). The bacterial group most consistently affected by PAR was the SAR11 clade; $25 \%$ more SAR11 bacteria used leucine in the light than the total community. The study illustrates the complex effects of light on single-cell activity of bacterial groups and helps to explain the variability in the impact of light on dissolved organic carbon fluxes.
\end{abstract}

KEY WORDS: Microautoradiography $\cdot$ Bacterial activity $\cdot$ Light $\cdot$ DOM incorporation

\section{INTRODUCTION}

The number of bacteria actively using dissolved organic material (DOM), as assessed by single-cell assays, varies greatly within aquatic habitats for reasons that are not completely understood (Smith \& del Giorgio 2003, del Giorgio \& Gasol 2008). Some of this variation is related to changes in the phylogenetic composition of bacterial communities. The abundances of even broad phylogenetic groupings, such as those recognized by commonly used fluorescence in situ hybridization (FISH) probes, vary in response to different environmental properties, including DOM availability (Amann et al. 1990b, Amann \& Fuchs 2008). There is evidence that these broad groups of bacteria also differ in their use of organic material (Cottrell \& Kirchman 2000, Longnecker et al. 2006, Elifantz et al. 2007). For example, more cells in the Alphaproteobacteria class use low molecular weight compounds like amino acids or glucose than high molecular weight compounds such as protein or polysaccharides (Cottrell \& Kirchman 2000, Elifantz et al. 2005, Alonso-Saez et al. 2009). Within the Alphaproteobacteria, more than half of the ubiquitous SAR11 clade incorporated amino acids and dimethylsulfoniopropionate (DMSP) in the North Atlantic (Malmstrom et al. 2004). However, the fractions of SAR11 that use polysaccharides and protein are smaller than those that use low molecular weight material such as leucine and other amino acids (Elifantz et al. 2005, Malmstrom et al. 2005). The single-cell activity of Gammaproteobacteria using different compounds does not vary overall in western Arctic waters (Elifantz et al. 2007). In contrast, the fraction of Gammaproteobacteria that uses glucose is smaller than those that use other compounds in both the Mediterranean Sea and the Delaware Estuary (Elifantz et al. 2005, Alonso-Saez \& Gasol 2007).

The use of DOM by these broad bacterial groups may shift in response to many environmental factors, some 
of which vary seasonally (Fuhrman et al. 2006, Henriques et al. 2006). In Blanes Bay in the northwest Mediterranean Sea, more Gammaproteobacteria incorporated amino acids in winter than in summer (AlonsoSaez \& Gasol 2007). Active fractions of Gammaproteobacteria and the Sphingobacteria-Flavobacteria group increased with higher concentrations of glucose during a spring phytoplankton bloom in the North Sea (Alonso \& Pernthaler 2006). Mortality due to grazing or viral lysis also impacts bacterial activity, and there is some evidence of differing responses by different bacterial groups as well as a greater response in oligotrophic systems (Longnecker et al. 2010). In the California Current System, the fraction of cells in the whole bacterial community using leucine responded to changes in temperature and salinity but there were no differences in the responses of the bacterial groups studied, including Sphingobacteria-Flavobacteria and the Alpha-, Beta-, and Gammaproteobacteria (Longnecker et al. 2006). The environmental factors driving variation in single-cell activity of specific bacterial groups are not well characterized.

The ability of some heterotrophic bacteria to use light as an additional source of energy may drive variation in growth and abundance (Kolber et al. 2000, Béjá et al. 2001). Exposure to photosynthetically active radiation (PAR) can stimulate the total community uptake of compounds such as leucine and methionine (Moran et al. 2001, Church et al. 2004, Mary et al. 2008), but the effect may not always be present or the same (Michelou et al. 2007). Some of the light effect may be due to proteorhodopsin, a potential lightharvesting mechanism found in many bacterial taxa (Béjá et al. 2000, de la Torre et al. 2003, Morris et al. 2010). A cultured Flavobacteria strain containing proteorhodopsin grew faster in the light than in the dark (Gómez-Consarnau et al. 2007), and cultured Vibrio survived starvation better with proteorhodopsin than without it (Gómez-Consarnau et al. 2010). However, other cultured proteorhodopsin-bearing strains have not responded to PAR in experiments conducted so far (Giovannoni et al. 2005, Stingl et al. 2007). In the environment, stimulation of bacterial activity by light exposure may be offset by light inhibition. Alonso-Saez et al. (2006) observed higher sensitivity to UV light in the Alphaproteobacteria, while other groups such as the Gammaproteobacteria and Bacteroidetes were more resistant to photo-damage. More work is necessary to determine the effects of light on different bacterial groups.

The goal of this study was to identify the variation in single-cell activity of different bacterial groups in the lower Delaware Bay in response to environmental properties. We hypothesized that substrate use by bacterial groups varies with molecular weight of the sub- strate, related to PAR exposure. We tested the incorporation of leucine (an index for bacterial biomass production), protein, and a mixture of 15 amino acids in both light and dark by selected phylogenetic groups in summer and fall. Over the $3 \mathrm{yr}$ of the study, single-cell activity varied among the compounds and groups, and was both stimulated and inhibited by light, depending on the compound and the bacterial group.

\section{MATERIALS AND METHODS}

Surface waters were sampled monthly at the mouth of the Delaware Bay (site 'Bay') and $18.5 \mathrm{~km}$ offshore (site 'FB') from 2006 to 2009 (www.ocean.udel.edu/ $\mathrm{cms}$ /dkirchman/MOPE). Abundance of all prokaryotes was measured using epifluorescence microscopy with 4'-6-diamidino-2-phenylindole (DAPI) staining (Porter \& Feig 1980, Cottrell et al. 2006). Concentrations of chlorophyll $a$, dissolved organic carbon (DOC) and dissolved organic nitrogen (DON) were estimated by standard methods (Parsons et al. 1984, Benner \& Strom 1993, Sharp et al. 1995). Surface PAR was measured using a Biospherical light meter.

Bulk bacterial production. Bacterial production was estimated by the microcentrifuge method from incorporation of ${ }^{3} \mathrm{H}$-leucine ( $20 \mathrm{nM}$, final concentration) in 30 min incubations at in situ temperatures in the dark (Smith \& Azam 1992, Kirchman 2001). Bulk growth rates were calculated by dividing bacterial production ( $\mathrm{mg} \mathrm{C} \mathrm{m}^{-3} \mathrm{~d}^{-1}$ ) by biomass ( $\mathrm{mg} \mathrm{C} \mathrm{m}^{-3}$ ), assuming conversion factors of $20 \mathrm{fg} \mathrm{C}$ cell $^{-1}$ and $1.5 \mathrm{~kg} \mathrm{C}$ per mole of leucine (Lee \& Fuhrman 1987, Kirchman et al. 2009). Additionally, bulk incorporation of ${ }^{3} \mathrm{H}$-leucine in the light was measured using $6 \mathrm{~h}$ incubations in clear plastic bags (Whirlpak, Nasco) exposed to PAR from a metal halide lamp (Hydrofarm). Light intensity from the lamp was $1 \times 10^{16}$ quanta $\mathrm{s}^{-1} \mathrm{~cm}^{-2}$. Mean surface PAR at the time of sampling was $8 \times 10^{16}$ quanta $\mathrm{s}^{-1}$ $\mathrm{cm}^{-2}$. The dark incubations were the same except that the bags were covered in double-layered black plastic. These conditions were also used for single-cell assays described below.

Abundance of bacterial groups. The abundance of selected bacterial taxa was estimated using catalyzed reporter deposition fluorescence in situ hybridization (CARD-FISH; Pernthaler et al. 2002). Water samples were fixed overnight at $4^{\circ} \mathrm{C}$ with paraformaldehyde (PFA, 2\% final concentration). Samples were filtered through $0.22 \mu \mathrm{m}$ polycarbonate filters (Millipore) with a $0.45 \mu \mathrm{m}$ nitrocellulose support filter (Millipore), rinsed with $0.22 \mu \mathrm{m}$ filtered deionized water, and stored at $-20^{\circ} \mathrm{C}$ until further processing. Probes for Alphaproteobacteria (Alf968), Gammaproteobacteria (Gam42a), SAR11 clade (SAR11-441r), all bacteria 
(EUB338) and a negative control were used (Amann et al. 1990a, Manz et al. 1992, Karner \& Fuhrman 1997, Glöckner et al. 1999, Morris et al. 2002). Cells were embedded on the filter using $0.1 \%$ agarose then treated with lysozyme to increase permeability. Filter pieces were hybridized with horseradish peroxidaselabeled oligonucleotide probes, and subsequently stained with cyanine-3 (Cy3)-labeled tyramides (TSA kit, Perkin Elmer). Following this staining, the filter pieces were either processed for microautoradiography (see below) or transferred onto slides and stained

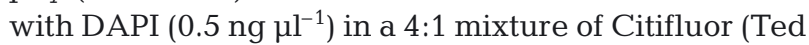
Pella) and Vectashield (Vector Labs) anti-fading mountants.

Single-cell assay of bacterial activity. The incorporation of selected compounds by specific bacterial groups was examined using microautoradiography combined with CARD-FISH (Micro-FISH) on samples taken in the summer and fall (see Fig. 1). Water samples for Micro-FISH were incubated with $20 \mathrm{nM}{ }^{3} \mathrm{H}$ leucine (Perkin Elmer), a mixture of 15 tritiated amino acids including leucine $(0.5 \mathrm{nM}$, American

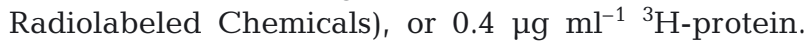
${ }^{3} \mathrm{H}$-protein was extracted from a Vibrio alginolyticus culture fed with ${ }^{3} \mathrm{H}$-leucine (Nagata et al. 1998). Leucine was added at saturating concentrations to examine bacterial biomass production, while the incorporation of tracer concentrations of amino acids and protein provided a measure of DOM use. Incubations in clear polycarbonate bottles with leucine or the amino acid mixture lasted $2 \mathrm{~h}$ and protein incubations lasted $6 \mathrm{~h}$ at in situ temperatures in the dark or exposed to PAR as described above. After incubation, samples were fixed with PFA ( $2 \%$ final concentration) overnight at $4^{\circ} \mathrm{C}$ and filtered as for FISH. PFA was added to killed controls prior to the addition of labeled compounds.

Microautoradiography was carried out as described by Cottrell \& Kirchman (2003). Slides were dipped in film emulsion (Amersham Hypercoat EM-1), then filter pieces were placed cell-side down onto the emulsion. A time series of exposure in the emulsion before developing was used to select the shortest time required to identify a maximum number of active cells. The exposure time for leucine samples was $24 \mathrm{~h}$, for amino acids 3 to $4 \mathrm{~d}$, and for protein samples $6 \mathrm{~d}$. At the end of the exposure time, slides were developed and fixed (Dektol developer and fixer, Kodak). After drying overnight, the filter pieces were carefully peeled away and the cells stained with DAPI in the $4: 1$ mountant as described above.
Cells were counted using a semi-automated microscope system, described previously by Cottrell \& Kirchman (2003). Ten fields of view were counted for each sample, with a constant exposure time of $100 \mathrm{~ms}$ for silver grain images. DAPI image exposure times ranged from 75 to $100 \mathrm{~ms}$, and Cy3 image exposure times were set by the negative control and ranged from 300 to $500 \mathrm{~ms}$. The proportion of the total community that was active was calculated as the number of DAPI-stained objects with associated silver grain clusters divided by the total number of DAPI-stained objects. Similarly, the number of probe- and DAPIstained objects with silver grains was divided by the total number of probe- and DAPI-positive cells to calculate the percentage of a group that actively took up a given compound. Non-specific probe binding was below $5 \%$ for all samples. All percentage data were arcsine-transformed for statistical analyses.

\section{RESULTS}

We examined the influence of environmental changes on variation in abundance and single-cell activity of different bacterial groups in the lower Delaware Bay over 3 yr. Environmental properties at the 2 sites varied over time (Table 1). PAR and the concentrations of DOC and DON did not differ between seasons. Bulk ${ }^{3} \mathrm{H}$-leucine incorporation and temperature peaked in the fall, whereas total bacterial abundance was highest in late summer. Bacterial abundance averaged $4.76 \pm 0.83 \times 10^{6}$ cells $\mathrm{ml}^{-1}$ over all samples (Fig. 1). Chlorophyll a concentrations correlated positively with bacterial abundance $(\mathrm{r}=0.70, \mathrm{~N}=78, \mathrm{p}<$ $0.05)$ and temperature $(\mathrm{r}=0.78, \mathrm{~N}=78, \mathrm{p}<0.05) .{ }^{3} \mathrm{H}-$ leucine incorporation correlated with temperature $(\mathrm{r}=$ 0.74, $\mathrm{N}=70, \mathrm{p}<0.05$ ) (Fig. 1) and bacterial abundance $(\mathrm{r}=0.53, \mathrm{~N}=70, \mathrm{p}<0.05)$. As the environmental properties from the 2 sites did not differ significantly, the results from both stations were combined for analyses.

Table 1. Environmental properties and bulk bacterial characteristics during sampling in the Delaware Bay. Mean \pm SE of 6 samples in the summer and 8 samples in the fall

\begin{tabular}{|lccc|}
\hline Property & Summer & Fall & Mean \\
\hline Environmental properties & & & \\
Water temperature $\left({ }^{\circ} \mathrm{C}\right)$ & $17 \pm 1.7$ & $19 \pm 1.5$ & $18 \pm 1.1$ \\
$\mathrm{Chl}$ a concentration $\left(\mu \mathrm{l} \mathrm{l}^{-1}\right)$ & $5.2 \pm 0.02$ & $9.9 \pm 0.02$ & $7.9 \pm 0.11$ \\
PAR $\left(\right.$ quanta $\left.\mathrm{cm}^{-2} \mathrm{~s}^{-1} \times 10^{17}\right)$ & $0.81 \pm 0.17$ & $0.71 \pm 0.15$ & $0.75 \pm 0.11$ \\
Dissolved organic carbon $\left(\mu \mathrm{mol} \mathrm{l}^{-1}\right)$ & $98 \pm 0.01$ & $101 \pm 0.1$ & $99 \pm 0.2$ \\
Dissolved organic nitrogen $\left(\mu \mathrm{mol} \mathrm{l}^{-1}\right)$ & $8.9 \pm 0.04$ & $13 \pm 0.02$ & $11 \pm 0.14$ \\
Bacterial characteristics & & & \\
Abundance $\left(\right.$ cells $\left.\mathrm{ml}^{-1} \times 10^{6}\right)$ & $8.1 \pm 0.65$ & $3.7 \pm 0.12$ & $5.6 \pm 0.22$ \\
Leucine incorporation $\left(\mathrm{pmol} \mathrm{l}^{-1} \mathrm{~h}^{-1}\right)$ & $460 \pm 0.5$ & $260 \pm 0.3$ & $360 \pm 0.5$ \\
\hline
\end{tabular}



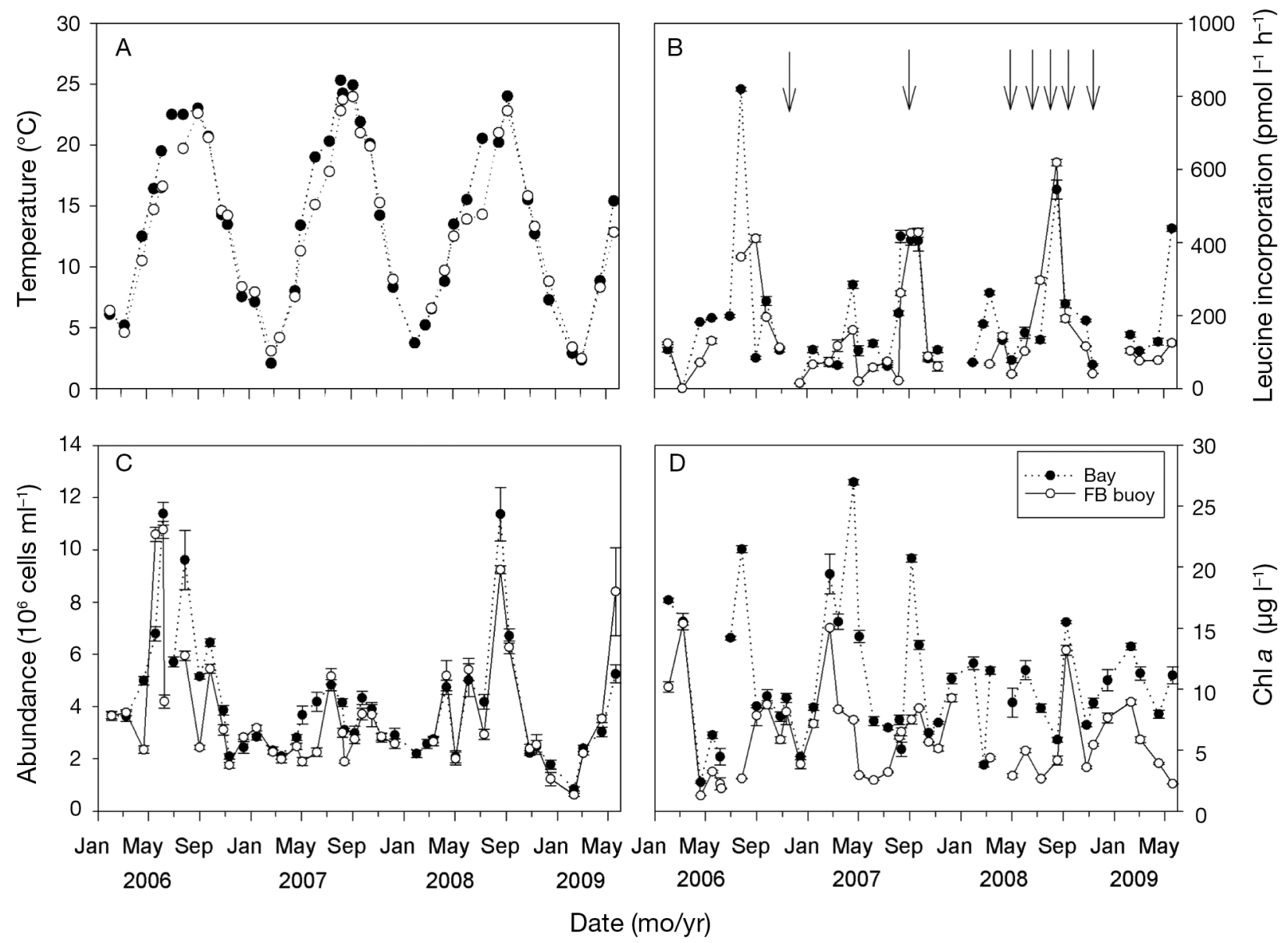

Fig. 1. (A) Temperature, (B) bulk ${ }^{3} \mathrm{H}$-leucine incorporation, (C) bacterial abundance, and (D) concentrations of chlorophyll a in Delaware Bay (Bay) and coastal waters (FB buoy). Arrows indicate times of Micro-FISH sampling. Error bars are $1 \mathrm{SE}$

\section{Abundance of bacterial groups}

We analyzed the relative abundance of selected bacterial groups using CARD-FISH. Gammaproteobacteria and Alphaproteobacteria were equally abundant, each accounting for around $25 \%$ of the community. SAR11 abundance averaged $15 \%$ (coefficient of variation $[\mathrm{CV}]=0.78$ ) of the total microbial abundance. Relative Gammaproteobacteria abundance varied more than the other groups $(\mathrm{CV}=0.98)$ and positively correlated with bulk ${ }^{3} \mathrm{H}$-leucine incorporation, temperature, and concentrations of DOC and DON (Table 2). Alphaproteobacterial abundance $(\mathrm{CV}=0.58)$ did not vary significantly with environmental conditions, but SAR11 abundance was negatively correlated with bacterial abundance, temperature and chlorophyll a concentration (Table 2). Sphingobacteria-Flavobacteria averaged $9.8 \%$ relative abundance in initial samples from both stations in the summer and fall of 2007 ( $n=7$, data not
Table 2. Pearson correlation coefficients between relative abundances of Gammaproteobacteria (Gamma-), Alphaproteobacteria (Alpha-) and SAR 11, and environmental variables. $\mathrm{N}$ is the number of dates examined over $3 \mathrm{yr} .{ }^{*} \mathrm{p}<0.05$, ${ }^{* *} \mathrm{p}<0.01$

\begin{tabular}{|lccc|}
\hline Property & Gamma- & Alpha- & SAR11 \\
\hline Temperature & $0.31^{*}$ & 0.001 & $-0.37^{* *}$ \\
Chl a concentration & 0.08 & -0.12 & $-0.36^{* *}$ \\
Bacterial abundance & 0.15 & -0.07 & $-0.32^{*}$ \\
Bacterial production & $0.38^{* *}$ & 0.09 & -0.12 \\
Dissolved organic carbon & $0.25^{*}$ & 0.22 & 0.22 \\
Dissolved organic nitrogen & $0.26^{*}$ & 0.18 & 0.20 \\
N & 64 & 71 & 63 \\
\hline
\end{tabular}

shown). Due to the low abundance of the group, the abundance of the active cells was near the detection limit for Micro-FISH. As a result of this methodological limitation Sphingobacteria-Flavobacteria were not examined further. 
Table 3. Fraction of groups incorporating the indicated compounds in light and dark incubations conducted over 3 yr. Mean \% $\pm \mathrm{SE}$ of 11 to 14 samples of total community or 16 to 30 samples for bacterial groups. AA mix is the mixture of 15 amino acids

\begin{tabular}{|c|c|c|c|c|c|c|}
\hline Bacterial group & $\begin{array}{l}\text { Leucine } \\
\text { light }\end{array}$ & $\begin{array}{c}\text { Leucine } \\
\text { dark }\end{array}$ & $\begin{array}{c}\text { AA mix } \\
\text { light }\end{array}$ & $\begin{array}{l}\text { AA mix } \\
\text { dark }\end{array}$ & $\begin{array}{c}\text { Protein } \\
\text { light }\end{array}$ & $\begin{array}{c}\text { Protein } \\
\text { dark }\end{array}$ \\
\hline All cells & $28 \pm 3$ & $32 \pm 4$ & $28 \pm 4$ & $33 \pm 5$ & $7 \pm 1$ & $11 \pm 3$ \\
\hline Bacteria $^{a}$ & $25 \pm 2$ & $30 \pm 3$ & $27 \pm 7$ & $26 \pm 4$ & $8 \pm 1$ & $13 \pm 4$ \\
\hline Gammaproteobacteria & $36 \pm 5$ & $34 \pm 5$ & $21 \pm 6$ & $25 \pm 4$ & $11 \pm 3$ & $10 \pm 3$ \\
\hline Alphaproteobacteria & $59 \pm 6$ & $60 \pm 3$ & $36 \pm 11$ & $33 \pm 9$ & $10 \pm 3$ & $13 \pm 4$ \\
\hline SAR11 & $51 \pm 6$ & $46 \pm 6$ & $20 \pm 6$ & $21 \pm 5$ & $4 \pm 2$ & $7 \pm 2$ \\
\hline
\end{tabular}

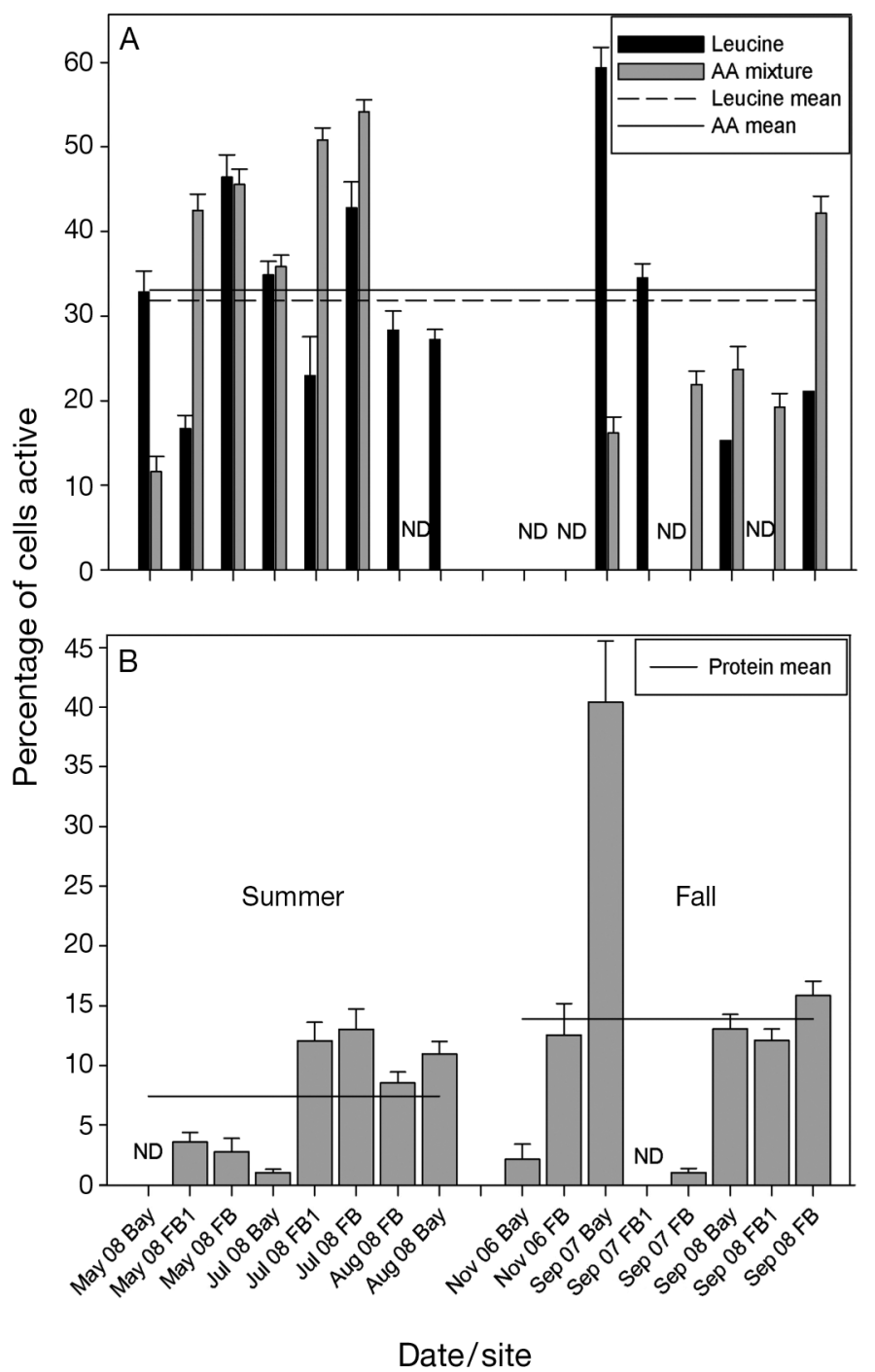

Fig. 2. Single-cell incorporation of (A) leucine and an amino acid (AA) mixture and (B) protein by the bacterial community in the dark. FB1 samples were taken at site FB (see 'Materials and methods' for details of sites) during the night (no night samples were taken in Nov 06 or Aug 08). Horizontal lines indicate mean fractions incorporating a compound. Error bars are $1 \mathrm{SE} . \mathrm{ND}=$ no data

\section{Single-cell incorporation of DOM}

Incorporation of DOM by bacteria differed among the substrates examined, and varied with environmental properties. About $31 \%$ of total DAPI-stained cells were active in dark incubations (incorporating leucine at saturating concentrations), and a similar fraction (33\%) incorporated the amino acid mixture (Table 3, Fig. 2). In contrast, only $11 \%$ of cells on average incorporated protein. The percentage of cells taking up leucine decreased with total bacterial abundance (Table 4). The fractions of the bacterial community incorporating leucine and amino acids negatively correlated with chlorophyll a concentration ( $\mathrm{r}=-0.47$ and -0.33 , respectively), while the fraction using protein positively correlated with chlorophyll a concentration ( $\mathrm{r}=0.42$, Table 4$)$. The proportion of the bacterial community using protein also positively correlated with temperature and bacterial abundance (Table 4).

Incorporation of DOM in the dark varied within groups and among the different groups (Table 3). Fewer EUB338-positive cells incorporated protein $(13 \%)$ than were active in incorporating leucine or the amino acid mixture (both about 30\%). Greater proportions of Alpha- and Gammaproteobacteria actively incorporated leucine than protein, but for both groups the fraction incorporating the amino acid

Table 4. Pearson correlation coefficients of environmental variables and the fraction of the total community incorporating a given compound. $\mathrm{N}$ is number of samples taken over 3 yr. AA mix is the mixture of 15 amino acids. ${ }^{*} p<0.05$, ${ }^{* *} \mathrm{p}<0.01$

\begin{tabular}{|lccccc|}
\hline Compound & Temp. & $\begin{array}{c}\text { Secchi } \\
\text { depth }\end{array}$ & $\begin{array}{c}\text { Chl a } \\
\text { conc. }\end{array}$ & $\begin{array}{c}\text { Bacterial } \\
\text { abundance }\end{array}$ & $\mathrm{N}$ \\
\hline Leucine & -0.33 & $0.42^{*}$ & $-0.47^{* *}$ & $-0.41^{*}$ & 31 \\
AA mix & -0.28 & 0.18 & $-0.33^{*}$ & -0.24 & 37 \\
Protein & $0.40^{*}$ & -0.17 & $0.42^{* *}$ & $0.45^{* *}$ & 39 \\
\hline
\end{tabular}



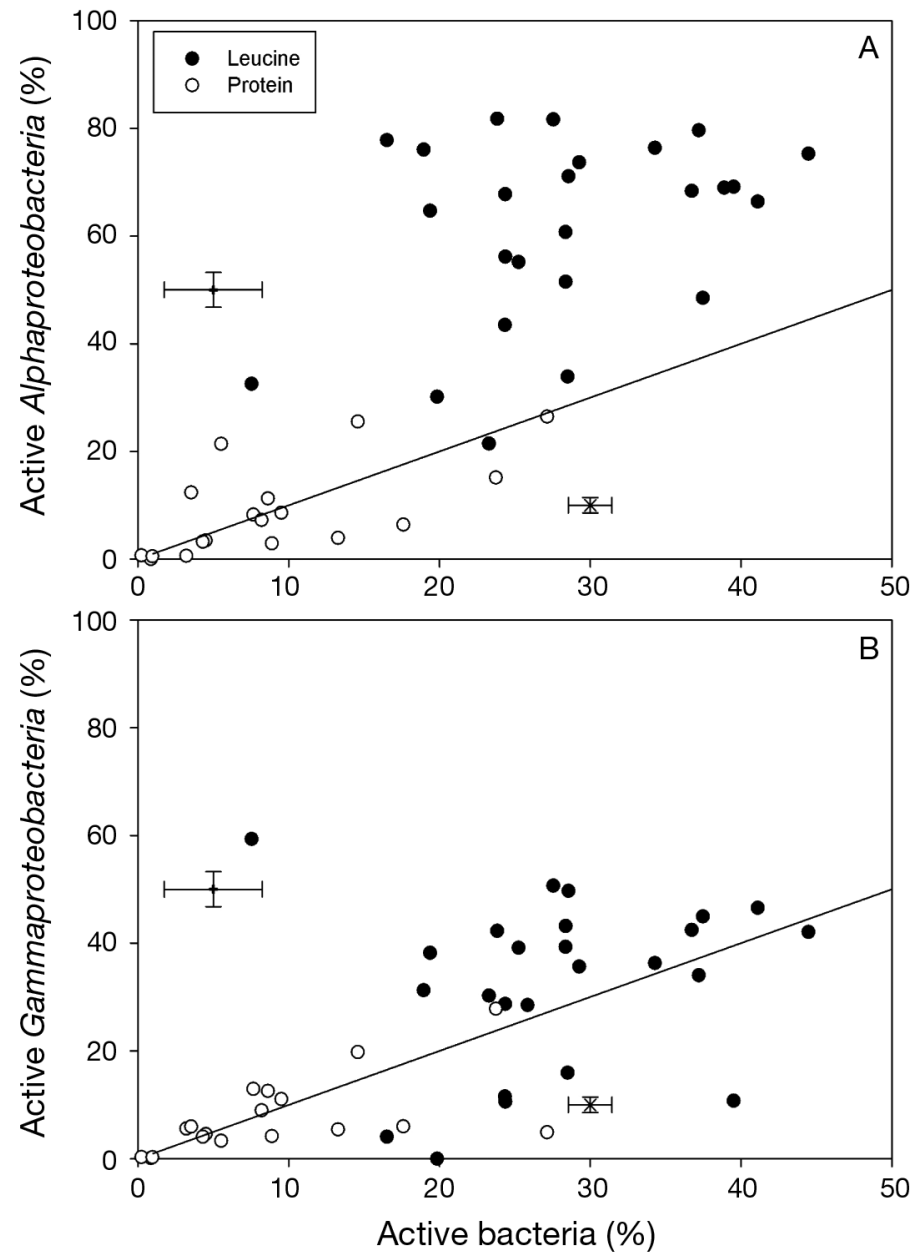

Fig. 3. Incorporation of leucine and protein by Alpha- and Gammaproteobacteria compared to the total bacterial community (EUB338-labeled cells) in the dark in experiments conducted from 2006 to 2008. Line is the 1:1 line. The mean standard errors are indicated for leucine $(+)$ and protein $(x)$

mixture did not differ significantly from the leucineactive fraction or the fraction incorporating protein (Table 3, see Figs. S2-4 in the supplement at www.int-res.com/articles/suppl/a062p267_supp.pdf). In dark experiments, more Alphaproteobacteria incorporated leucine than Gammaproteobacteria and the total community; Gammaproteobacteria and the total community did not differ (Fig. 3). The fraction of SAR11 incorporating leucine in the dark did not differ from the other groups. Although alphaproteobacterial abundance did not vary significantly with environmental conditions (Table 2), the fraction of the Alphaproteobacteria that used all compounds negatively correlated with bacterial production $(\mathrm{r}=-0.25$, $\mathrm{N}=69, \mathrm{p}=0.038)$ and the concentration of DOC $(\mathrm{r}=$ $-0.24, \mathrm{~N}=67, \mathrm{p}=0.045$ ).
We compared bacterial activity between summer (late May to August) and fall (September to November) in 16 dark incubations (Fig. 2, see Fig. S1 in the supplement at www.int-res.com/articles/suppl/a062 p267_supp.pdf for light incubations). Environmental conditions did not differ significantly among years, and seasons from different years were combined for analysis. Bulk growth rates did not differ between summer and fall, averaging $0.11 \pm 0.02 \mathrm{~d}^{-1}$, and the fraction of cells that used leucine was also the same in both seasons (Table 1). The total fraction of cells incorporating protein was 2-fold higher in the fall than in the summer, while the incorporation of the amino acid mixture did not differ between the 2 seasons. A larger proportion of Gammaproteobacteria actively used leucine in the summer $(45 \%)$ than in the fall $(23 \%)$. More Alphaproteobacteria and SAR11 incorporated amino acids in the summer (50 and $28 \%$, respectively) than in the fall (23 and 16\%, respectively). Likewise, more SAR11 used protein in the summer $(10 \%)$ than in the fall $(2 \%)$.

\section{Effects of light exposure}

Occasionally, PAR had significant effects on total ${ }^{3} \mathrm{H}$-leucine incorporation and on single-cell activity. Overall, bulk ${ }^{3} \mathrm{H}$-leucine incorporation did not differ between light and dark in $6 \mathrm{~h}$ experiments conducted over $2 \mathrm{yr}$, but in some individual cases light did have an effect (Fig. 4). Single-cell activity of the total community using the 3 compounds was affected by PAR in 6 out of 35 experiments; 3 were stimulated by light while 3 had higher activity in the dark (Table 5). In

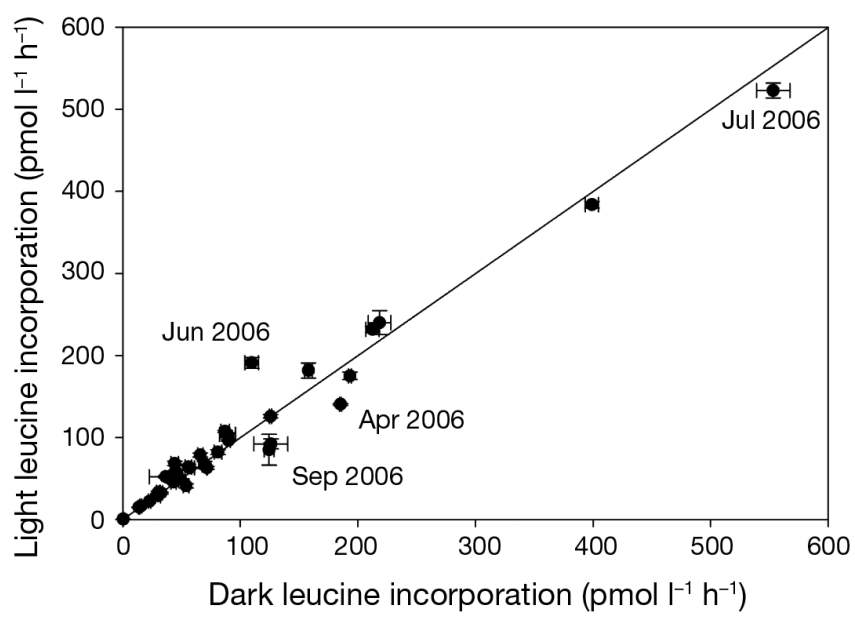

Fig. 4. Bulk ${ }^{3} \mathrm{H}$-leucine incorporation in light vs. dark incubations in experiments conducted from 2006 to 2008 . Line is the 1:1 line. Error bars are 1 SE. Sample dates for selected cases of the greatest light effect are noted 
Table 5. Response to photosynthetically active radiation (PAR) by the total community and bacterial groups. No. is the number of experiments with a significant difference within the group tested (ANOVA, $p<0.05$ ) between dark and light incubations. The total number of experiments conducted over 3 yr was 11 to 13 for total samples and 9 to 15 for groups. The percent stimulation or inhibition by PAR was calculated as (Activity Light $_{-}$-Activity Dark $_{\text {) }}$ /Activity Dark, $_{\text {, }}$ and means of the affected samples are reported here. These means were all greater than the mean variance in single-cell activity within a sample, as determined from replicate counts $(32 \%, n=23)$

\begin{tabular}{|c|c|c|c|c|c|c|}
\hline \multirow[t]{2}{*}{ Bacterial group } & \multirow[t]{2}{*}{ Compound } & \multicolumn{2}{|c|}{ Stimulated } & \multicolumn{2}{|c|}{ Inhibited } & \multirow{2}{*}{$\begin{array}{l}\text { No. un- } \\
\text { affected }\end{array}$} \\
\hline & & & & No. & $\%$ & \\
\hline Total & Amino acids & 1 & 149 & 2 & -68 & 8 \\
\hline Total & Leucine & 2 & 113 & 0 & - & 9 \\
\hline Total & Protein & 0 & - & 1 & -67 & 12 \\
\hline Bacteria $^{a}$ & Amino acids & 1 & 251 & 1 & -97 & 6 \\
\hline Bacteria & Leucine & 1 & 276 & 0 & - & 14 \\
\hline Bacteria & Protein & 0 & - & 4 & -72 & 5 \\
\hline Alphaproteobacteria & Amino acids & 2 & 218 & 2 & -84 & 4 \\
\hline Alphaproteobacteria & Leucine & 0 & - & 0 & - & 15 \\
\hline Alphaproteobacteria & Protein & 0 & - & 2 & -77 & 7 \\
\hline Gammaproteobacteria & Amino acids & 0 & - & 2 & -91 & 6 \\
\hline Gammaproteobacteria & Leucine & 3 & 271 & 1 & -100 & 11 \\
\hline Gammaproteobacteria & Protein & 2 & 171 & 1 & -95 & 6 \\
\hline SAR11 & Amino acids & 0 & - & 0 & - & 8 \\
\hline SAR11 & Leucine & 1 & 353 & 0 & - & 14 \\
\hline SAR11 & Protein & 1 & 100 & 2 & -95 & 6 \\
\hline
\end{tabular}

for leucine and the amino acid mixture, and the incorporation of protein by EUB338-positive cells was even more strongly inhibited by light with roughly half of the experiments inhibited. Bacteria responded to light with a change in single-cell incorporation in about $25 \%$ of protein and amino acid mixture experiments, while only $11 \%$ of leucine experiments were affected, consistent with the low number of cases in which bulk leucine incorporation was affected by PAR.

Single-cell activity of bacterial groups responded to light in a similar proportion $(20 \%)$ of cases as singlecell activity of the total community (Table 5). There was a similar number of cases of light stimulation and light inhibition, but the magnitude of response was approximately 2-fold greater in cases of light stimulation (mean 211\% stimulation and $85 \%$ inhibition). Alpha- and Gammaproteobacteria did not differ in their response to light (Table 5), except that

the 2 leucine assays with significant differences, only stimulation of single-cell activity by light was observed. In 1 experiment, protein was taken up by significantly more cells in the dark than in the light. For amino acid incorporation, both stimulation and inhibition by PAR occurred (Table 5). The response by EUB338-labeled cells matched that of the total cells

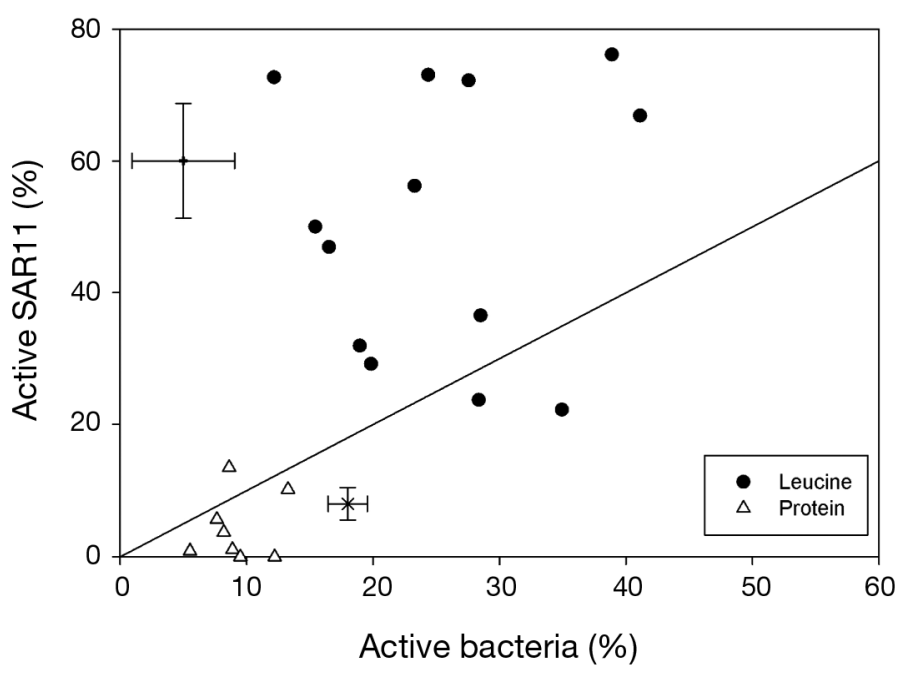

Fig. 5. Incorporation of leucine and protein by SAR11 bacteria compared to the total community in the light in experiments conducted from 2006 to 2008. Line is the 1:1 line. The mean standard errors are indicated for leucine $(+)$ and protein $(x)$
Alphaproteobacteria was the only group for which light stimulated amino acid incorporation. Gammaproteobacteria and SAR11 both responded to light with changes in the fractions using leucine and protein, but both stimulation and inhibition by light occurred (Table 5). About 25\% more SAR11 cells than bacterial cells (EUB338-positive) used leucine when exposed to light (ANOVA p < 0.05, Fig. 5). In light incubations, more Gammaproteobacteria incorporated protein than SAR11 cells, though the difference was only about $7 \%$ (Table 3).

Light conditions prior to sampling may affect the bacterial response to PAR (Alonso-Saez et al. 2006). To explore this effect, we examined the relationship between light conditions prior to sampling and the single-cell responses in our assays (Table 6). The fraction of the total bacterial community that used the amino acid mixture correlated negatively with the mean PAR during the $3 \mathrm{~d}$ preceding sampling $(\mathrm{r}=-0.66, \mathrm{p}<0.05$, $n=11$ ), but there was no relationship for leucine or protein single-cell activity. Light-affected single-cell incorporation of leucine negatively correlated with PAR at sampling and the integrated PAR during the sampling day (Table 6). In contrast, the magnitude of the light effect on incorporation of the amino acid mixture correlated negatively with the mean and peak PAR during the $3 \mathrm{~d}$ prior to sampling. Light-affected protein incorporation did not correlate with light conditions prior to sampling. 
Table 6. Correlation between the significant light effect on single-cell activity for a given compound (Light - Dark) and light environment. The number of samples was 11 to 13 taken over 3 yr. AA: amino acid. ${ }^{*} \mathrm{p}<0.05$

\begin{tabular}{|c|c|c|c|}
\hline & Leucine & AA mixture & Protein \\
\hline Date $^{a}$ & 0.32 & 0.04 & 0.23 \\
\hline PAR at sampling & $-0.66^{*}$ & -0.24 & -0.39 \\
\hline Mean PAR ${ }^{b}$ & -0.01 & $-0.66^{*}$ & 0.26 \\
\hline Peak PAR ${ }^{c}$ & -0.06 & $-0.69^{*}$ & 0.02 \\
\hline Sampling time ${ }^{\mathrm{d}}$ & -0.57 & -0.06 & -0.05 \\
\hline \multicolumn{4}{|c|}{$\begin{array}{l}{ }^{\mathrm{a}} \text { Time of year } \\
{ }^{\mathrm{b}} \text { Mean from 08:00-16:00 } \mathrm{h} \text { during the } 3 \mathrm{~d} \text { preceding sam- } \\
\text { pling } \\
{ }^{\mathrm{c} P e a k} \text { during 08:00-16:00 } \mathrm{h} \text { averaged over the } 3 \mathrm{~d} \text { pre- } \\
\text { ceding sampling } \\
{ }^{\mathrm{d}} \text { Time of day }\end{array}$} \\
\hline
\end{tabular}

\section{DISCUSSION}

The abundance of broad phylogenetic groups of bacteria differs among locations and varies with environmental properties (Eilers et al. 2001, Kirchman et al. 2005, Longnecker et al. 2006). Causes for this variation in abundance and activity, including DOM incorporation, are still uncertain. The aim of this study was to assess the abundance of broad bacterial groups and their use of DOM in relation to light and other environmental factors. Temperate estuaries like the Delaware Bay are useful model systems because they change greatly over the seasons (Pennock \& Sharp 1986). Our results add to data showing differences in substrate use by broad phylogenetic groups in marine environments, including both seasonal changes and the use of compounds with different molecular weight (Cottrell \& Kirchman 2000, 2003, Elifantz et al. 2007). We found variation in abundance and single-cell activity with environmental conditions, including light exposure.

Bacterial group activity differs among compounds of different molecular weight. The fraction of the total bacterial community using low molecular weight amino acids was similar to the fraction using leucine, but only about a third of all leucine-active cells incorporated the high molecular weight protein. High fractions of Alphaproteobacteria have been seen to use low molecular weight substrates (Cottrell \& Kirchman 2000, Longnecker et al. 2006, Alonso-Saez \& Gasol 2007). Our results agree with these findings, as more cells of Alphaproteobacteria used leucine than the high molecular weight protein. Members of the Bacteroidetes, predominantly Sphingobacteria and Flavobacteria in marine systems, use high molecular weight material (Cottrell \& Kirchman 2000, Kirchman et al. 2005, Malmstrom et al. 2007). The low abundance of
Sphingobacteria-Flavobacteria in these samples may explain in part the low fraction of cells using protein.

Some studies have tracked the single-cell activity of bacterial groups over seasons (Alderkamp et al. 2006, Alonso-Saez et al. 2007, 2008), but the factors resulting in changes in the abundance of broad bacterial groups remain largely unknown (Cottrell \& Kirchman 2003, Alderkamp et al. 2006, Longnecker et al. 2006). The abundance and activity of Alpha- and Gammaproteobacteria appear to be controlled by different environmental pressures. In our study, the abundance of total Alphaproteobacteria did not vary with environmental properties, suggesting a role for top-down factors. The number of leucine-active Alphaproteobacteria increased when grazing and viral abundance were reduced in experiments using oligotrophic waters (Longnecker et al. 2010). In contrast, the abundance of Gammaproteobacteria did vary significantly with several properties during our study. Other studies have also observed that gammaproteobacterial abundance changes with environmental conditions, including phytoplankton blooms and grazer abundance (Alderkamp et al. 2006, Teira et al. 2008, Longnecker et al. 2010). This group is thought to be specialized to DOMrich conditions (Kirchman et al. 2005, Alonso-Saez et al. 2007). Whereas Gammaproteobacteria are a small fraction of the total community in other marine systems (Alonso-Saez et al. 2007), we found high gammaproteobacterial abundance in the estuary and coastal waters we examined. In our study, the correlation between gammaproteobacterial abundance and total bacterial production, as well as concentrations of DOC and DON, supports the hypothesis that this group is specialized for highly productive conditions (Rehnstam et al. 1993, Eilers et al. 2000).

The SAR11 clade is ubiquitous in many marine environments, but the fraction of the group active in DOM incorporation varies (Rappé et al. 2002, Alonso \& Pernthaler 2006, Straza et al. 2010). In the North Atlantic, SAR11 cells have been found to contribute to about half of the leucine and glucose incorporation by the total community, but they are not dominant in the assimilation of protein (Malmstrom et al. 2005). Alonso \& Pernthaler (2006) observed a higher proportion of Roseobacter cells using glucose than SAR11 cells, consistent with other studies demonstrating variation in glucose use by different types of SAR11 bacteria (Schwalbach et al. 2010). Previous studies have also shown that SAR11 abundance varies seasonally in the Mid-Atlantic Bight and the northwest Mediterranean Sea (Alonso-Saez \& Gasol 2007, Campbell et al. 2009). The data presented here provide further evidence that SAR11 cells are active in marine waters and respond to environmental changes. The abundance of SAR11 varied, and the fraction using amino acids and protein 
changed between summer and fall. Overall, leucine incorporation by SAR11 cells was stimulated by PAR, in agreement with other results suggesting that SAR11 bacteria in natural communities can use light to supplement energy requirements (Campbell et al. 2009, Lami et al. 2009).

The use of sunlight for energy has been identified as a factor potentially influencing heterotrophic bacterial growth (Kolber et al. 2000, Béjà et al. 2001). The discoveries of aerobic anoxygenic phototrophic bacteria and the presence of rhodopsin genes in many divisions of bacteria necessitate reconsideration of bacterial responses to light and the subsequent impact on DOM cycling (Kolber et al. 2000, Béjà et al. 2001). The light responses of a few bacterial groups have been analyzed, including the incorporation of leucine by Prochlorococcus and Synechococcus in the light (Church et al. 2004, Michelou et al. 2007). Expression of the proteorhodopsin gene was upregulated in Flavobacteria and the SAR11 clade during microcosm experiments with Delaware coastal waters exposed to PAR, though continuous light did not stimulate growth (Lami et al. 2009). The mechanisms by which light affects bacteria may vary among groups, and include stimulation of both ATP production and membrane transport (Morris et al. 2010). However, light can also have negative effects, which vary among bacterial groups. Alonso-Saez et al. (2006) found that single-cell activity of Alphaproteobacteria was more affected by prior exposure to UV light than was the activity of Gammaproteobacteria cells. One of the effects of UV irradiation may be a switch from lysogenic to lytic state in bacteria infected by viruses (Weinbauer \& Suttle 1996). In addition to UV, our results suggest that even PAR can have negative effects on single-cell activity of various bacterial groups, as observed in a few of the light exposure experiments and in the negative correlations between light availability and bulk leucine incorporation. The magnitude of a light effect on bacterial activity, as seen by leucine incorporation, was diminished with greater light exposure prior to our sampling, indicating a potential delayed effect from over-exposure to light (Alonso-Saez et al. 2006).

PAR had a direct effect on bacterial activity in about $20 \%$ of our experiments. Rather than a uniform stimulation, the result of light exposure differed between groups and among substrate types, and depended upon natural light conditions prior to sampling. This variability may be due to the abundance and activity of SAR11 bacteria, a large fraction of which have proteorhodopsin genes (Giovannoni et al. 2005, Campbell et al. 2009). SAR11 bacteria, like other members of the Alphaproteobacteria, use low molecular weight compounds more than high molecular weight compounds (Malmstrom et al. 2005, Straza et al. 2010). Light use by
SAR11 bacteria helps to explain why the magnitude of activity stimulation by light was much greater than inhibition by light and why the use of high molecular weight DOM (protein) did not change with previous light conditions.

Some of the variability in light effects observed in this study and by others (Alonso-Saez et al. 2006, Michelou et al. 2007) may be due in part to methodological limitations. As a result of long doubling times, the bacterial community may take several hours or more to respond to changes. We had to keep these whole-water sample incubations short to avoid 'bottle effects' and limitation of labeled substrate, as well as indirect effects of light through production of DOM by photoautotrophs and grazers. Determining the number of active bacteria by microautoradiography may not detect some effects of light. Also, the bacteria analyzed in this study were broad phylogenetic groups, and even the clade of SAR11 is very diverse (Carlson et al. 2009). The integrated response of a broad group may have masked differences in response by sub-groups, as we observed with Alphaproteobacteria and SAR11.

\section{CONCLUSIONS}

In this study, we describe the impact of environmental conditions on the single-cell activity of bacteria in a temperate estuary and coastal waters. Environmental changes resulted in characteristic differences in the use of organic compounds by broad phylogenetic groups of bacteria. Like other environmental factors, light has a complex effect on bacterial communities. The broad groups tested here responded differently to light, but more work is needed, including exploring the responses of bacterial groups at finer phylogenetic levels. Characterizing the role of light in the regulation of bacterial activity is an important component of understanding the contribution of bacterial groups to biogeochemical processes.

Acknowledgements. This research was supported by NSF grant MCB-0453993 to D.L.K. We thank M. Cottrell, V. Michelou, and other members of the Kirchman laboratory for assistance with sampling, and 3 anonymous reviewers for their helpful comments.

\section{LITERATURE CITED}

Alderkamp AC, Sintes E, Herndl GJ (2006) Abundance and activity of major groups of prokaryotic plankton in the coastal North Sea during spring and summer. Aquat Microb Ecol 45:237-246

Alonso C, Pernthaler J (2006) Roseobacter and SAR11 dominate microbial glucose uptake in coastal North Sea waters. Environ Microbiol 8:2022-2030 
Alonso-Saez L, Gasol JM (2007) Seasonal variations in the contributions of different bacterial groups to the uptake of low-molecular-weight compounds in northwestern Mediterranean coastal waters. Appl Environ Microbiol 73: 3528-3535

Alonso-Saez L, Gasol JM, Lefort T, Hofer J, Sommaruga R (2006) Effect of natural sunlight on bacterial activity and differential sensitivity of natural bacterioplankton groups in northwestern Mediterranean coastal waters. Appl Environ Microbiol 72:5806-5813

Alonso-Saez L, Balague V, Sa EL, Sanchez O and others (2007) Seasonality in bacterial diversity in north-west Mediterranean coastal waters: assessment through clone libraries, fingerprinting and FISH. FEMS Microbiol Ecol 60:98-112

Alonso-Saez L, Sanchez O, Gasol JM, Balague V, Pedrós-Alió C (2008) Winter-to-summer changes in the composition and single-cell activity of near-surface Arctic prokaryotes. Environ Microbiol 10:2444-2454

Alonso-Saez L, Unanue M, Latatu A, Azua I, Ayo B, Artolozaga I, Iriberri J (2009) Changes in marine prokaryotic community induced by varying types of dissolved organic matter and subsequent grazing pressure. J Plankton Res 31:1373-1383

Amann R, Fuchs BM (2008) Single-cell identification in microbial communities by improved fluorescence in situ hybridization techniques. Nat Rev Microbiol 6:339-348

Amann RI, Binder BJ, Olson RJ, Chisholm SW, Devereux R, Stahl DA (1990a) Combination of 16S rRNA-targeted oligonucleotide probes with flow cytometry for analyzing mixed microbial populations. Appl Environ Microbiol 56: 1919-1925

Amann RI, Krumholz L, Stahl DA (1990b) Fluorescentoligonucleotide probing of whole cells for determinative, phylogenetic, and environmental studies in microbiology. J Bacteriol 172:762-770

Béjà O, Aravind L, Koonin EV, Suzuki MT and others (2000) Bacterial rhodopsin: evidence for a new type of phototrophy in the sea. Science 289:1902-1906

Béjà O, Spudich EN, Spudich JL, Leclerc M, DeLong EF (2001) Proteorhodopsin phototrophy in the ocean. Nature 411:786-789

Benner R, Strom M (1993) A critical evaluation of the analytical blank associated with DOC measurements by hightemperature catalytic oxidation. Mar Chem 41:153-160

> Campbell BJ, Yu L, Straza TRA, Kirchman DL (2009) Temporal changes in bacterial rRNA and rRNA genes in Delaware (USA) coastal waters. Aquat Microb Ecol 57: 123-135

Carlson CA, Morris R, Parsons R, Treusch AH, Giovannoni SJ, Vergin K (2009) Seasonal dynamics of SAR11 populations in the euphotic and mesopelagic zones of the northwestern Sargasso Sea. ISME J 3:283-295

Church MJ, Ducklow HW, Karl DA (2004) Light dependence of $\left[{ }^{3} \mathrm{H}\right]$ leucine incorporation in the oligotrophic North Pacific ocean. Appl Environ Microbiol 70:4079-4087

> Cottrell MT, Kirchman DL (2000) Natural assemblages of marine proteobacteria and members of the CytophagaFlavobacter cluster consuming low- and high-molecularweight dissolved organic matter. Appl Environ Microbiol 66:1692-1697

Cottrell MT, Kirchman DL (2003) Contribution of major bacterial groups to bacterial biomass production (thymidine and leucine incorporation) in the Delaware estuary. Limnol Oceanogr 48:168-178

> Cottrell MT, Mannino A, Kirchman DL (2006) Aerobic anoxygenic phototrophic bacteria in the Mid-Atlantic Bight and the North Pacific Gyre. Appl Environ Microbiol 72: $557-564$

de la Torre JR, Christianson LM, Béjá O, Suzuki MT, Karl DM, Heidelberg J, DeLong EF (2003) Proteorhodopsin genes are distributed among divergent marine bacterial taxa. Proc Natl Acad Sci USA 100:12830-12835

del Giorgio PA, Gasol JM (2008) Physiological structure and single-cell activity in marine bacterioplankton. In: Kirchman DL (ed) Microbial ecology of the oceans. Wiley-Liss, Hoboken, NJ, p. 243-298

- Eilers H, Pernthaler J, Glöckner FO, Amann R (2000) Culturability and in situ abundance of pelagic bacteria from the North Sea. Appl Environ Microbiol 66:3044-3051

> Eilers H, Pernthaler J, Peplies J, Glöckner FO, Gerdts G, Amann R (2001) Isolation of novel pelagic bacteria from the German Bight and their seasonal contributions to surface picoplankton. Appl Environ Microbiol 67: $5134-5142$

Elifantz H, Malmstrom RR, Cottrell MT, Kirchman DL (2005) Assimilation of polysaccharides and glucose by major bacterial groups in the Delaware Estuary. Appl Environ Microbiol 71:7799-7805

- Elifantz H, Dittell AI, Cottrell MT, Kirchman DL (2007) Dissolved organic matter assimilation by heterotrophic bacterial groups in the western Arctic Ocean. Aquat Microb Ecol 50:39-49

> Fuhrman JA, Hewson I, Schwalbach MS, Steele JA, Brown MV, Naeem S (2006) Annually reoccurring bacterial communities are predictable from ocean conditions. Proc Natl Acad Sci USA 103:13104-13109

- Giovannoni SJ, Bibbs L, Cho JC, Stapels MD and others (2005) Proteorhodopsin in the ubiquitous marine bacterium SAR11. Nature 438:82-85

Glöckner FO, Fuchs BM, Amann R (1999) Bacterioplankton compositions of lakes and oceans: a first comparison based on fluorescence in situ hybridization. Appl Environ Microbiol 65:3721-3726

Gómez-Consarnau L, González JM, Coll-Lladó M, Gourdon P and others (2007) Light stimulates growth of proteorhodopsin-containing marine Flavobacteria. Nature 445: $210-213$

Gómez-Consarnau L, Akram N, Lindell K, Pedersen A and others (2010) Proteorhodopsin phototrophy promotes survival of marine bacteria during starvation. PLoS Biol 8: e1000358

- Henriques IS, Alves A, Tacao M, Almeida A, Cunha A, Correia A (2006) Seasonal and spatial variability of free-living bacterial community composition along an estuarine gradient (Ria de Aveiro, Portugal). Estuar Coast Shelf Sci 68: 139-148

Karner M, Fuhrman JA (1997) Determination of active marine bacterioplankton: a comparison of universal 16S rRNA probes, autoradiography, and nucleoid staining. Appl Environ Microbiol 63:1208-1213

Kirchman DL (2001) Measuring bacterial biomass production and growth rates from leucine incorporation in natural aquatic environments. Methods Microbiol 30:227-237

Kirchman DL, Dittel AI, Malmstrom RR, Cottrell MT (2005) Biogeography of major bacterial groups in the Delaware Estuary. Limnol Oceanogr 50:1697-1706

> Kirchman DL, Hill V, Cottrell MT, Gradinger R, Malmstrom RR, Parker A (2009) Standing stocks, production, and respiration of phytoplankton and heterotrophic bacteria in the western Arctic Ocean. Deep-Sea Res II 56:1237-1248

Kolber ZS, Van Dover CL, Niederman RA, Falkowski PG (2000) Bacterial photosynthesis in surface waters of the open ocean. Nature 407:177-179 
Lami R, Cottrell MT, Campbell BJ, Kirchman DL (2009) Lightdependant growth and proteorhodopsin expression by Flavobacteria and SAR11 in experiments with Delaware coastal waters. Environ Microbiol 11:3201-3209

Lee S, Fuhrman JA (1987) Relationships between biovolume and biomass of naturally derived marine bacterioplankton. Appl Environ Microbiol 53:1298-1303

Longnecker K, Homen DS, Sherr EB, Sherr BF (2006) Similar community structure of biosynthetically active prokaryotes across a range of ecosystem trophic states. Aquat Microb Ecol 42:265-276

Longnecker K, Wilson MJ, Sherr EB, Sherr BF (2010) Effect of top-down control on cell-specific activity and diversity of active marine bacterioplankton. Aquat Microb Ecol 58: 153-165

Malmstrom RR, Kiene RP, Cottrell MT, Kirchman DL (2004) Contribution of SAR11 bacteria to dissolved dimethylsulfoniopropionate and amino acid uptake in the North Atlantic Ocean. Appl Environ Microbiol 70:4129-4135

Malmstrom RR, Cottrell MT, Elifantz H, Kirchman DL (2005) Biomass production and assimilation of dissolved organic matter by SAR11 bacteria in the Northwest Atlantic Ocean. Appl Environ Microbiol 71:2979-2986

Malmstrom RR, Straza TRA, Cottrell MT, Kirchman DL (2007) Diversity, abundance, and biomass production of bacterial groups in the western Arctic Ocean. Aquat Microb Ecol 47:45-55

Manz W, Amann R, Ludwig W, Wagner M, Schleifer K (1992) Phylogenetic oligodeoxynucleotide probes for the major subclasses of Proteobacteria - problems and solutions. Syst Appl Microbiol 15:593-600

- Mary I, Tarran GA, Warwick PE, Terry MJ, Scanlan DJ, Burkill PH, Zubkov MV (2008) Light enhanced amino acid uptake by dominant bacterioplankton groups in surface waters of the Atlantic Ocean. FEMS Microbiol Ecol 63: $36-45$

> Michelou VK, Cottrell MT, Kirchman DL (2007) Light-stimulated bacterial production and amino acid assimilation by cyanobacteria and other microbes in the North Atlantic Ocean. Appl Environ Microbiol 73:5539-5546

> Moran XAG, Massana R, Gasol JM (2001) Light conditions affect the measurement of oceanic bacterial production via leucine uptake. Appl Environ Microbiol 67: 3795-3801

Morris RM, Rappé MS, Connon SA, Vergin KL, Siebold WA, Carlson CA, Giovannoni SJ (2002) SAR11 clade dominates ocean surface bacterioplankton communities. Nature 420: 806-810

Morris RM, Nunn BL, Frazar C, Goodlett DR, Ting YS, Rocap G (2010) Comparative metaproteomics reveals oceanscale shifts in microbial nutrient utilization and energy transduction. ISME J 4(5):673-685

Editorial responsibility: Karel Šimek, České Budějovice, Czech Republic
Nagata T, Fukuda R, Koike I, Kogure K, Kirchman DL (1998) Degradation by bacteria of membrane and soluble protein in seawater. Aquat Microb Ecol 14:29-37

Parsons TR, Maita Y, Lalli C (1984) A manual of chemical and biological methods for seawater analysis. 1st edn. Pergamon Press, Oxford

> Pennock JR, Sharp JH (1986) Phytoplankton production in the Delaware Estuary: temporal and spatial variability. Mar Ecol Prog Ser 34:143-155

Pernthaler A, Pernthaler J, Amann R (2002) Fluorescence in situ hybridization and catalyzed reporter deposition for the identification of marine bacteria. Appl Environ Microbiol 68:3094-3101

> Porter K, Feig Y (1980) The use of DAPI for identifying and counting aquatic microflora. Limnol Oceanogr 25:943-948

Rappé MS, Connon SA, Vergin KL, Giovannoni SJ (2002) Cultivation of the ubiquitous SAR11 marine bacterioplankton clade. Nature 418:630-633

Rehnstam AS, Backman S, Smith DC, Azam F, Hagström A (1993) Blooms of sequence-specific culturable bacteria in the sea. FEMS Microbiol Ecol 102:161-166

Schwalbach MS, Tripp HJ, Steindler L, Smith DP, Giovannoni SJ (2010) The presence of the glycolysis operon in SAR11 genomes is positively correlated with ocean productivity. Environ Microbiol 12:490-500

Sharp JH, Benner R, Bennett L, Carlson CA, Fitzwater SE, Peltzer ET, Tupas LM (1995) Analyses of dissolved organic carbon in seawater - the JGOFS EQPAC methods comparison. Mar Chem 48:91-108

Smith DC, Azam F (1992) A simple, economical method for measuring bacterial protein synthesis rates in sea water using ${ }^{3} \mathrm{H}$-leucine. Mar Microb Food Webs 6:107-114

Smith EM, del Giorgio PA (2003) Low fractions of active bacteria in natural aquatic communities? Aquat Microb Ecol 31:203-208

> Stingl U, Desiderio RA, Cho JC, Vergin KL, Giovannoni SJ (2007) The SAR92 clade: an abundant coastal clade of culturable marine bacteria possessing proteorhodopsin. Appl Environ Microbiol 73:2290-2296

Straza TRA, Ducklow HW, Murray AE, Kirchman DL (2010) Abundance and single-cell activity of bacterial groups in Antarctic coastal waters. Limnol Oceanogr 55:2526-2536

> Teira E, Gasol JM, Aranguren-Gassis M, Fernandez A, Gonzalez J, Lekunberri I, Álvarez Salgado XA (2008) Linkages between bacterioplankton community composition, heterotrophic carbon cycling and environmental conditions in a highly dynamic coastal ecosystem. Environ Microbiol 10: 906-917

Weinbauer MG, Suttle CA (1996) Potential significance of lysogeny to bacteriophage production and bacterial mortality in coastal waters of the Gulf of Mexico. Appl Environ Microbiol 62:4374-4380

Submitted: June 4, 2010; Accepted: October 13, 2010 Proofs received from author(s): January 25, 2011 